\title{
SCHIZOFRENIE V ČESKÉM PROSTŘEDÍ: DISKURZIVNÍ ANALÝZA VÝPOVĚDÍ O SCHIZOFRENII ${ }^{1}$
}

\author{
Jan Pokluda
}

\begin{abstract}
Abstrakt
Předkládaná výzkumná studie se zabývá zmapováním diskurzů o schizofrenii v českém prostředí. V rámci výzkumu byly prováděny polostrukturované rozhovory o schizofrenii s laiky, s lidmi s diagnózou a s odborníky $(\mathrm{N}=15)$. Přepsané rozhovory byly následně analyzovány jedním z př́stupů diskurzivní analýzy - kritickou diskurzivní psychologií. Celkem bylo identifikováno 13 odlišných interpretačních repertoárů, které respondenti využívali pro konstruování schizofrenie a člověka s diagnózou. Také byly zmapovány pozice, které tyto repertoáry umožňují zaujmout, důsledky, jaké identifikované repertoáry přináší, a repertoáry byly zasazeny do globálních diskurzů. Respondenti zaujímali větší množství mnohdy protichůdných repertoárů. $\mathrm{V}$ diskusi byly následně konfrontovány výsledky s relevantními studiemi. Dále byly popsány limity předkládané studie a návrhy možných navazujících výzkumů a aplikace do praxe.
\end{abstract}

Klíčová slova: schizofrenie, diskurz, interpretační repertoár, kritická diskurzivní psychologie

\section{SCHIZOPHRENIA IN THE CZECH ENVIRONMENT: DISCOURSIVE ANALYSIS OF INTERVIEWS ON SCHIZOPHRENIA}

\begin{abstract}
The presented research study deals with the mapping of discourses on schizophrenia in the Czech environment. The research conducted semi-structured interviews on schizophrenia with lay people, people with diagnosis and experts $(N=15)$. Those transcribed interviews were subsequently analyzed by one of the discoursive analysis approach - critical discursive psychology. Overall, 13 different interpretative repertoires used by respondents for the construction of schizophrenia and schizophrenic people were identified. Positions that could be hold thanks to these repertoires and consequences of these repertoires were also described. Respondents used a larger number of often conflicting repertoires. Results were confronted with relevant studies in discussion. Further, limits of this study were described as well as suggestions of possible follow-up research and practical application.
\end{abstract}

Keywords: schizophrenia, discourse, interpretative repertoire, critical discursive psychology

Došlo: 1. 11. 2019

Schváleno: 3. 11. 2020

\footnotetext{
${ }^{1}$ Předkládaná výzkumná studie vychází z autorovy rigorózní práce, ve které je možné nalézt obsáhlejší informace o zkoumané oblasti. Pokluda, J. (2018). Schizofrenie v českém diskurzu. Rigorózní práce. Brno: Filozofická fakulta, Masarykova univerzita.
} 


\section{Úvod}

Pojem schizofrenie je s námi již více než sto let (Št’astný, 2008), jeho chápání se v průběhu této doby proměňovalo a jednotlivé výklady schizofrenie se vyvíjely s rozvojem poznání duševních nemocí (Šafářová, 2011). V posledních letech bylo publikováno množství zahraničních studií (Angermeyer \& Matschinger, 2005; Broussard, Goulding, Talley, \& Compton, 2010; Compton, Esterberg, \& Broussard, 2008; Furnham \& Blythe, 2012; Leiderman et al., 2011; Marie \& Miles, 2008; Olafsdottir \& Pescosolido, 2011; Richards, Hori, Sartorius, \& Kunugi, 2014; Sawamura et al., 2012; Swami, Furnham, Kannan, \& Sinniah, 2008), které se zabývaly laickým chápáním schizofrenie často spolu s postojem $\mathrm{k}$ lidem s diagnózou schizofrenie. Ve většině těchto studií se objevuje stigmatizační akcent a je v nich zkoumáno, nakolik jsou lidé schopni rozpoznat projevy psychózy. Mnohdy je $\mathrm{v}$ nich podtrhováno, $\mathrm{v}$ čem se veřejnost dané oblasti ve svém chápání schizofrenie mýlí. Z výše uvedených studií je zřejmé, že se chápání pojmu schizofrenie i postoje veřejnosti ke schizofrenii liší $\mathrm{v}$ jednotlivých zemích a kulturách, proto má smysl zabývat se chápáním pojmu schizofrenie i v naší zemi.

Nevýhodou většiny zmíněných studií je, že nezachycují představu respondenta o schizofrenii v celé její šíři, ale obvykle ji zužují do několika kategorií, které respondenti vybírají v daném dotazníku. V předkládané studii je zachycována představa osob o schizofrenii komplexněji, prostřednictvím rozhovorů a následné diskurzivní analýzy. Obdobných studií, které by se zabývaly představou veřejnosti o schizofrenii více do hloubky, je pouze několik.

Porovnáváním sociálních reprezentací schizofrenie u lidí s touto diagnózou a u laické veřejnosti se zabývala pouze francouzská studie (Castillo, Lannoy, Seznec, Januel, \& Petitjean, 2008). Bylo v ní zjišsěno, že mezi veřejností převažovala reprezentace schizofrenie jako zdravotního problému. To je autory chápáno jako pozitivní vývoj reprezentace schizofreniků, kteří jsou společností vnímáni spíše jako nemocní než jako šílení. Překvapivé rovněž je, že u pacientů se schizofrenií i u laiků existují stejné nebo velmi podobné sociální reprezentace týkající se stigmatu schizofreniků. Autoři předpokládají, že lidé s diagnózou schizofrenie ze společnosti tyto reprezentace internalizovali.

Studie (Rudge \& Morse, 2001) zaměřená na způsob, jakým lidé s diagnózou konstruují svoji úzdravu, došla k poměrně překvapivému zjištění. V literatuře bývá uzdravování ze schizofrenie popisováno jako lineární proces, na jehož konci v ideálním př́ípadě schizofrenie jakoby zmizí ze života dotyčného. V této studii však bylo zjištěno, že tomu tak vủbec být nemusí. Podle výsledků tohoto australského výzkumu se člověk se svou diagnózou v rámci úzdravy učí žít. Tento proces však není lineární. Nalezení vhodné niky, v níž může člověk se schizofrenií koexistovat, může být náhlou a jednorázovou událostí. Zároveň schizofrenie nikam nezmizí, ale stává se centrální součástí identity dotyčného.

Pokud jde o studie, v jejichž rámci byla prováděna analýza diskurzu, existuje několik studií zabývajících se diskurzy, v nichž je konstruována duševní nemoc. Za pozornost stojí výzkum (Bilić \& Georgaca, 2007), jehož předmětem byl obraz duševní nemoci v srbských novinách, jejichž obsah byl sledován po dobu dvou let. Byla v něm prováděna kritická diskurzivní analýza, pomocí níž byly identifikovány tři rozdílné diskurzy. Jednalo se o diskurz spojující duševní nemoc s projevy agrese a pácháním násilné trestné činnosti. Dále o biomedicínský diskurz, v jehož rámci je duševně nemocným přisuzována pasivní role. Poslední diskurz dával do souvislosti sociopolitické změny se vzrůstajícím počtem duševně nemocných, což podle autorů vychází ze specifického srbského kontextu. 
Z prostředí České republiky bylo doposud publikováno pouze několik výzkumů na související témata, navíc byly často zaměřovány spíše na postoj veřejnosti ke schizofrenikům a na stigma. Nawková a kol. (2010) se zabývali vyobrazením duševně nemocného v médiích. Proběhlo zde také rozsáhlé dotazníkové šetření (DEMA, 2004), zaměřené především na stigma schizofrenie, kterého se účastnilo 667 respondentů. $Z$ výsledků bylo zjištěno, že česká veřejnost sdílí určité stereotypní postoje, např́iklad představu, že psychické poruchy jsou neléčitelné a že psychicky nemocní jsou nevypočitatelní a agresivní. Co ale nebylo zkoumáno hlouběji, je samotné chápání konceptu schizofrenie, tedy to, jak byl v našem prostředí pojem vstřebán a jak je následně konstruován. Oblasti konstruování schizofrenie se v našem prostředí věnoval pouze Šupa $(2005 ; 2011)$, který zkoumal sociální reprezentace duševně nemocného u studentů a zabýval se také sociálním konstruováním pacientů s diagnózou schizofrenie zdravotnickými profesionály.

\section{Teoretická východiska}

Pokud jde o zkoumání společensky užívaného pojmu, jakým je schizofrenie, nabízí se řada teoretických rámců, které k tomu lze využít. Alfred Schütz pracuje s konceptem př́ruční zásoby vědění, která je souborem informací, jimiž disponuje každý, kdo je členem určité sociální skupiny (Schütz \& Wagner, 1970). Příruční zásoba vědění vychází ze zkušeností našich předků, našich současníků i nás samotných a pomáhá nám orientovat se a obstát ve světě (Urbánek, 1989). Schützova teorie tedy podtrhuje, že jednání člověka nikdy není izolované, ale vždy existuje v kontextu sociální reality, v níž se nachází (Schütz \& Wagner 1970). Člověk je tedy vybaven různými soubory vědění, z nichž některé s ním ostatní sdílejí a jiné nikoli. Z toho důvodu je pro člověka v sociálních interakcích důležitá znalost sociální distribuce vědění.

Další užitečnou teorií je v tomto směru koncept sociálních reprezentací. Sociální reprezentace jsou souborem postojů, názorů a přesvědčení, které se vytvářejí a přetrvávají ve společenských skupinách a které sjednocují porozumění světu prostřednictvím konsenzuální konstrukce reality (Plichtová, 1998). Sociální reprezentace (Moscovici, 2000) umožňují efektivní komunikaci s těmi, kteří je s námi sdílejí. Také umožňují systematickým způsobem uvažovat o vztazích jednotlivce a společnosti ve smyslu zaujetí pozice ve společenském diskurzu (Plichtová, 2002). Teorie sociálních reprezentací se zaměřuje na otázky, jakým způsobem se udržují a šíŕí určité hodnoty či přesvědčení. Všímá si také úlohy jazyka a utváření významů, přičemž sleduje jejich historický vývoj a stabilitu či změnu v čase a vztahuje je historickému a společenskému diskurzu (Plichtová, 2002). V tomto má teorie velmi blízko k sociálnímu konstrukcionismu v pojetí Bergera a Luckmanna (1999). Není tedy překvapivé, že na tuto teorii později navázala ze sociálního konstrukcionismu čerpající diskurzivní analýza (Vybíral, 2006), která se teorii sociálních reprezentací velmi podobá (Plichtová, 1998) a zároveň řeší některá ze slabých míst teorie sociálních reprezentací. ${ }^{2}$

Diskurzivní analýza je zároveň teorií a současně i metodou sběru a analýzy dat. Je pro ni př́źznačná analýza zpo̊sobů, kterými je realita konstituována v jazyce (Zábrodská, 2009). Pro analýzu dat předkládané studie byl zvolen jeden ze směrů analýzy diskurzu - kritická diskurzivní psychologie. Tento směr v sobě kombinuje detailní analýzu konkrétní verbální interakce či textu a makroanalýzu širších sociálních kontextů, v jejichž rámci text vznikl (Zábrodská, 2009; 2010). Tento směr se jeví jako velmi vhodný pro zkoumání určitého společensky konstruovaného pojmu či jevu a zjišt'ování toho, jaké důsledky mají dané konstrukce dotyčných pro jejich chování. V současné době již existuje větší množství studií

\footnotetext{
${ }^{2}$ Kritiku teorie sociálních reprezentací a konkrétnější důvody nahrazení diskurzivní analýzou autor rozebírá zevrubněji ve výše zmíněné rigorózní práci.
} 
zaměřujících se na analýzu společensky konstruovaného pojmu (Lafrance, 2007; Lafrance \& Stoppard, 2006; Öster, Åström, Lindh, \& Magnusson, 2009; Paulson \& Willig, 2008; Teräsahjo \& Salmivalli, 2003; Wilkinson, 2000), které tento směr využívají jako teoretické východisko či jako metodu analýzy dat.

Kritická diskurzivní psychologie na místo pojmu diskurz, kvůli jeho víceznačnosti, užívá pojem interpretační repertoár (Zábrodská \& Petrjánošová, 2013). Interpretační repertoáry jsou „souborem pojmů, popisů a řečnických obratů, často seskupených kolem metafor či živých obrazů [...], které jsou v řeči používány ke konstrukci odlišných verzí jednání, self a sociální struktury“ (Potter \& Wetherell, 1995, s. 89). Jde o historicky, kulturně a místně sdílený zdroj či suma významů, ze kterých mohou jedinci v dané kultuře, místě a čase čerpat významy, které přiřazují okolnímu světu (Zábrodská \& Petrjánošová, 2013). Interpretační repertoáry jsou flexibilnější a variabilnější než diskurzy (Potter \& Wiggins, 2007).

\section{Cíl výzkumu}

Cílem výzkumu je zmapovat, jaké významy a představy v našich kulturních podmínkách vstupují do subjektivního konstruování pojmu schizofrenie u laiků, lidí s touto diagnózou a u osob, které s lidmi s diagnostikovanou schizofrenií pracuji ${ }^{3}$. To by mělo pomoci lépe pochopit, jak lidé v našem prostředí toto onemocnění vnímají a jaké teorie se zde objevují. Dále je cílem zjistit, jaké důsledky identifikované konstrukce přináší, jaké diskurzivní pozice umožňují zaujmout a z jakých globálních diskurzů vychází.

\section{Výzkumný vzorek}

Výzkumný vzorek byl vybrán postupným určením výběrové struktury, což znamená, že o dalších respondentech, kteří byli do studie zahrnuti, bylo rozhodováno až na základě postupně vznikajících dat. Respondenti byli vybráni stratifikovaným účelovým výběrem, s cílem získání respondentů různého věku, vzdělání, s bydlištěm ve městě i na vesnici, se záměrem pokrýt co možná nejvíce potenciálních úhlů pohledu (Plichtová, 2002). Velikost výzkumného vzorku nebyla stanovena předem a vycházela z kritéria teoretické nasycenosti (Hendl, 2008). Noví respondenti již nebyli potřební ve chvíli, kdy další výzkumná data nepřinášela nové poznatky.

Výzkumu se účastnilo 19 respondentů (10 mužů a 9 žen) ve věku 25-65 let s různým vzděláním a z různého socioekonomického prostředí. Cílem bylo v následných rozhovorech zachytit co největší množství různých diskurzů týkajících se schizofrenie. Devět respondentů ( 5 žen a 4 muži) bylo $\mathrm{z}$ řad laické veřejnosti, pět respondentů ( 3 muži a 2 ženy) tvořili lidé s diagnostikovanou schizofrenií (klienti Sdružení Práh a pacienti Psychiatrické kliniky FN Brno) a pět respondentů ( 3 muži a 2 ženy) tvořili odborníci (psychologové, sociální pracovníci).

\section{Postup}

Design výzkumu vychází z předpokladu, že pojem schizofrenie je sociálně konstruovaným jevem, který $v$ rámci každodenní praxe podléhá změnám a je představován množstvím navzájem se prolínajících ale také rivalizujících diskurzů. Postup výzkumu byl veden dle 10 kroků, které navrhuje Potter a Wetherellová (1987) pro výzkumy využívající analýzu diskurzu. S respondenty byly prováděny polostrukturované rozhovory, které bývají vhodné ke zkoumání osobních teorií týkajících se určitého jevu (Flick, 2009). V rozhovorech byly kromě samotného významu pojmu schizofrenie nadneseny ještě další oblasti (příčiny a projevy schizofrenie,

\footnotetext{
${ }^{3}$ Dále pro zjednodušení označováni jako odborníci.
} 
osobní zkušenost respondenta se schizofrenií, léčba schizofrenie, kvalita života člověka $\mathrm{s}$ diagnózou, postoj k člověku s diagnózou). Díky této částečné strukturaci rozhovorů bylo při následné analýze dat možné snadněji identifikovat sdílené způsoby konstrukce jevů, což je u diskurzivní analýzy žádoucí (Zábrodská \& Petrjánošová, 2013).

Rozhovory s jednotlivými respondenty byly různě dlouhé (mezi 9 až 75 minutami), především v závislosti na šíři diskurzivních zdrojů respondenta o schizofrenii. Jeden rozhovor však trval pouze necelé 4 minuty. Šlo o specifickou situaci, kdy respondent nedisponoval žádnými diskurzivními zdroji ohledně zkoumaného pojmu. Jednotlivé rozhovory byly nahrávány na diktafon, vzniklé audiozáznamy byly detailně přepsány do textové podoby ${ }^{4}$ a následně analyzovány. K samotné analýze bylo zvoleno nakonec pouze 15 rozhovorů (s osmi muži a sedmi ženami), nebot' tři rozhovory s laiky už nepřinášely nové konstrukce jevů, což by mohlo svědčit o naplnění kritéria teoretické nasycenosti. Jeden rozhovor s člověkem s diagnózou nebyl použit z etických důvodů 5 .

Pokud jde o etický aspekt výzkumu, všichni respondenti se výzkumu účastnili dobrovolně a byli před samotným rozhovorem informováni o jeho účelu. Laikům a odborníkům bylo samotné téma rozhovoru sděleno bezprostředně před jeho provedením. Smyslem bylo zabránit jejich př́ípravě naprríklad v podobě čerpání informací o zkoumaném tématu. Osobám $\mathrm{s}$ diagnózou bylo, vzhledem k možné větší citlivosti tématu pro ně, sděleno samotné téma rozhovoru předem. Po provedení rozhovorů byl respondentům nabídnut debriefing v podobě poskytnutí informací o schizofrenii a probrání prrípadných otázek. Respondentům rovněž byla ve výzkumu zajištěna anonymita, která byla zachována i v přepisech rozhovorů.

Autor se během výzkumu průběžně vracel k reflexi vlastních předporozumění, vztahu $\mathrm{k}$ respondentům a celému zkoumanému tématu, a také se blíže zamýšlel nad kontextem rozhovorů, což je dle Miovského (2006) považováno za faktory, které vedou ke zvyšování validity.

\section{Analýza dat}

Pro analýzu textových dat byla zvolena diskurzivní analýza, která umožňuje odhalit, jak jsou významy schizofrenie respondenty konstruovány, a bývá využívána u obdobných výzkumů zaměřených na analýzu laických konstrukcí určitých jevů (např. Wilkinson, 2000). Konkrétně byla provedena kritická diskurzivní analýza, což je forma analýzy diskurzu, která propojuje mikro a makro analýzu diskurzu. Zaměřuje se jednak na použití a funkci řeči v sociální interakci, ale také na sdílené vzorce utváření významu a porozumění a jejich ideologické důsledky (Zábrodská \& Petrjánošová, 2013).

Při samotné analýze byl dodržován postup, který uvádí Zábrodská a Petrjánošová (2013) a Plichtová (2002). Text byl opakovaně čten, poté z něj byly vybrány vhodné, tedy vzhledem $\mathrm{k}$ výzkumné otázce relevantní, části $\mathrm{k}$ analýze. Následně z těchto částí textu byly identifikovány sdílené způsoby konstrukce jevu v podobě interpretačních repertoárů, které byly následně pojmenovány a zasazeny do globálních diskurzů. Poté bylo mapováno, co jednotlivé repertoáry způsobují a jaké subjektové pozice umožňují zaujmout.

K vlastnímu třídění témat byl využit program pro analýzu textových dat ATLAS/ti, který uživateli usnadňuje orientaci v textu a práci s ním (Hendl, 2008). Program umožňuje přiřazovat zvoleným částem textu kódy a následně např́íklad extrahovat tyto zvolené části mimo text, což se pro potřeby předkládané výzkumné studie ukázalo jako velmi užitečné.

\footnotetext{
${ }^{4}$ Za účelem zvýšení validity výzkumu jsou veškeré přepisy rozhovorů dostupné v př́loze rigorózní práce autora, aby bylo možné posoudit postup vyvozování závěrů.

${ }^{5}$ Nebylo zřejmé, zda respondent dobře pochopil účel a kontext výzkumu.
} 
Dokladem o tom, že identifikované interpretační repertoáry jsou sdílenými způsoby konstrukce jevů, je skutečnost, že se vyskytovaly ve větším množství rozhovorů - obvykle alespoň v polovině rozhovorů 6 .

\section{Výsledky}

Celkem bylo identifikováno 13 interpretačních repertoárů, prostřednictvím kterých laici, lidé s diagnózou schizofrenie a odborníci konstruují pojem schizofrenie. V následujících odstavcích jsou charakterizovány jednotlivé repertoáry, které jsou zároveň zasazeny do globálních diskurzů a s ohledem na přehlednost rovnou srovnávány s relevantními studiemi.

Repertoár „Schizofrenie jako rozdvojení osobnosti“ byl silně zastoupen především v konstrukcích laiků a mnohdy šlo o první konstrukci, která se v rozhovorech objevila. Rozdvojení osobnosti bylo definováno nekonzistencí a nepředvídatelností chování, což přináší důsledky v zaujímání pozice nejistoty, nepohody a legitimizuje ostražitost a odstup při kontaktu $\mathrm{s}$ člověkem s diagnózou. Repertoár vychází ze zkresleného mediálního obrazu a chybného etymologického chápání pojmu schizofrenie (Křesadlo, 2001). Studie Wilsona a kol. (1999) zjistila, že součástí diskurzivních zdrojů, jakými jsou duševně nemocní vykreslováni ve filmech, je často právě obraz nepředvídatelnosti, což by mohlo ukazovat na původ identifikované pozice, kterou tento repertoár umožňuje.

Repertoár „Schizofrenie jako něco, o čem se nemluví př́mo" byl identifikován $\mathrm{u}$ respondentů $\mathrm{z}$ řad laiků s osobní zkušeností s člověkem s diagnózou a u osob s diagnózou. $\mathrm{V}$ rámci této konstrukce je běžně namísto slova schizofrenie užíváno ukazovací zájmeno (,to maj doma“; „vono to furt něco komentuje ... furt to jako něco to furt jako řiká nějaký rüzný hnusný věci"). Tento repertoár umožňuje zaujetí pozice odstupu. Za touto konstrukcí může být vnímaná tíživost a závažnost schizofrenie jako nemoci a snaha distancovat se od ní, ale i empatizování s konkrétním člověkem. V rozhovorech sodborníky tento repertoár identifikován nebyl. Repertoár vychází z širšího diskurzu o tabuizovaných tématech. Zjišsění ohledně daného repertoáru jsou ve shodě s výsledky studie, která se zabývala repertoáry ve vztahu k rakovině, kde byla tato nemoc respondentkami s diagnózou konstruována obdobně, tedy jako něco nepojmenovatelného až tabuizovaného (Willig, 2008).

Interpretační repertoár, „Schizofrenie jako nemoc či psychická porucha“ byl zastoupen téměř ve všech rozhovorech. V rámci identifikovaného repertoáru je schizofrenie konstruována jako objektivně daná nemoc. Konkrétní konstrukce příčin, projevů a léčby se u jednotlivých respondentů $\mathrm{v}$ detailech lišily. Nejčastějším důsledkem daného repertoáru je nutnost podstoupit léčbu, která má charakter expertního zásahu. V rámci repertoáru je používán neosobní jazyk, chybí emočně zabarvená slova a je v něm zřejmý odstup. U laiků se objevovala pozice bezpečí a odstupu, kdy byla hospitalizace konstruována jako legitimní nápravný akt, který člověka s diagnózou izoluje od zbytku společnosti. Osobami s diagnózou byla zaujímána pozice pasivity, v níž je schizofrenik konstruován jako pasivní objekt experty prováděné léčby a ovlivnění často biologicky konstruované nemoci není v jeho moci. U odborníků a lidí s diagnózou se objevovaly bohatší a detailnější konstrukce, což patrně souvisí s tím, že jim je reprezentace schizofrenie jako nemoci bližší. Pro lidi s diagnózou bylo příznačné užívání zlidovělých výrazů (,Jsem pracovala no a marodila“). Také odborníky byli lidé s diagnózou v rámci tohoto repertoáru stavěni do pasivní pozice (,v reakci na nasazenou léčbu“). Ani odborníci se nestavěli do aktivní pozice, často užívali expertní jazyk a zastávali vůči lidem $\mathrm{s}$ diagnózou neosobní pozici. Zdá se, že v rámci repertoáru není mnoho prostoru pro aktivitu. Repertoár vychází z biomedicínského a psychiatrického diskurzu, který byl identifikován

\footnotetext{
${ }^{6}$ Jedinou výjimkou je repertoár „,neexistující reprezentace schizofrenie“, který se objevil v rozhovoru jediném.
} 
i v srbské studii (Bilić \& Georgaca, 2007). Boschma (2007) uvádí, že tento diskurz je postaven na mocenské nerovnosti pacienta a lékaře, a že nemocného může tento diskurz zneschopňovat v aktivitě, což se potvrdilo i v předkládané studii. Šupa (2011) rovněž uvádí, že v rámci psychiatrického diskurzu není príliš prostoru pro konstruování pacienta jako akceschopného a zodpovědného člověka, což podle něj otevírá prostor pro stigmatizaci.

Repertoár „Schizofrenie jako kariéra“ byl identifikován v rozhovorech s lidmi s diagnózou. $\mathrm{V}$ rámci tohoto repertoáru byla schizofrenie konstruována podobně jako profesní kariéra (,No, ten psychiatr mě předepsal ten Rispen ... ten okamžitě zabral a tím pádem on si jakoby ... on zjistil, že ... že to je teda ta daná choroba a tím pádem jsem se začal léčit na psychiatrii ... a tím vlastně začala ta moje kariéra ... hodně často ti pacienti hovoři jako o kariéř schizofrenika, takže tím se to jakoby rozběhlo tady tohleto. “). Je v něm užíván slovník z pracovní oblasti a sžívání s diagnózou je konstruováno jako aktivní práce. Se získanou schopností ovlivnit průběh schizofrenie se člověk posune kariérně výš. („,Pak pak se propracuješ do advanced, very advanced, jo? “). Konstruující má možnost dostat se v rámci tohoto repertoáru ze znevýhodněné pozice. Jak získává informace o diagnóze a učí se s ní žít, postupuje do profesně vyšší privilegované pozice, čímž si dokazuje kompetenci a schopnost zvládat překážky. Daný repertoár má společné prvky s konceptem úzdravy tak, jak jej definuje Pěč a kol. (2009). Úzdrava spočívá v procesu změny hodnot životních cílů, ale i schopností dotyčného, a umožňuje mu žít spokojený život i přes omezení způsobená onemocněním. Podobně jako v konceptu úzdravy byli i konstruující v identifikovaném repertoáru aktivními $\mathrm{v}$ procesu léčby a zaujímali pozici aktivity a kompetence.

Repertoár „Schizofrenie jako zátěž byl identifikován ve všech rozhovorech s lidmi s diagnózou. Schizofrenie je zde konstruována jako činitel, který dotyčnému komplikuje život a vyčerpává ho. Repertoár umožňuje zaujetí pozice spojené s aktivitou a volbou copingové strategie. Strategií může být boj („No, ehm já s tou schizofrenii bojuju už od 27 let, víte?“) nebo postupné vypořádávání se se schizofrenií (,... Pro mě nemoc, se kterou jsem se nevypořádal ještěc*). Důsledkem tohoto repertoáru je zaujetí ofenzivní pozice, v níž dotyčný zmobilizuje dostupné síly a prostředky ke zvládnutí zátěže. I když tento repertoár může být spjat s bolestí a strachem, $\mathrm{v}$ žádném $\mathrm{z}$ provedených rozhovorů nebyla identifikována pasivní poraženecká pozice. Lze tedy předpokládat, že u žádného z respondentů nenastala stresová fáze vyčerpání, která by dotyčnému znemožňovala aktivně čelit schizofrenii. Respondenti se patrně nacházeli ve stadiu rezistence (Paulík, 2010). Jak ukazuje polská studie (Libman-Sokolowka \& Nasierowski, 2013), v procesu vypořádávání se se schizofrenií hraje důležitou roli naděje a lze uvažovat, že u respondenti̊ v předkládané studii může být právě naděje jedním z prvků, které je staví do pozice aktivity, což by mohlo být předmětem dalšího zkoumání.

Repertoár ,Schizofrenie jako nálepka“ byl identifikován ve všech rozhovorech s odborníky. Do daného repertoáru spadají konstrukce, které vykreslují schizofrenii jako v jistém smyslu neužitečnou a stigmatizující nálepku. Konstruující v rámci tohoto repertoáru se schizofrenií operují jako s jevem, který reálně neexistuje, a jedná se jen o určitou člověkem vytvořenou kategorii. Konstruující zaujímali pozici naštvání ale i vyděšení se. Byli poměrně obezřetní při nakládání s pojmem schizofrenie a zajímali se o kontext, v jakém je s tímto pojmem zacházeno. Vyjadřovali uvědomění, že pojem schizofrenie může mít pro různé lidi mnoho významů a schová se pod něj „strašně moc věci“. Někteří konstruující raději pojem schizofrenie nepoužívají a mluví o komplexnějších projevech chování, což podle nich není stigmatizující. Spadají sem také konstrukce vyjadřující skepticismus k diagnostikování a jeho užitečnosti pro lidi s diagnózou. Daný repertoár vychází z globálního diskurzu o kategorizování, o kterém psal už Kant (2001). V psychologii má kritika nálepkování (labelingu) poměrně dlouhou tradici at' už v humanistických (Adamíková, 2003) či systemických př́stupech (Jonesová \& Ansen, 2004), ale také v kritické psychologii (Vybíral, 
2006). Někteří autoři (Jonesová \& Ansen, 2004) např́iklad mají za to, že právě nálepkování pomáhá udržovat problém a může být spouštěčem kariéry duševně nemocného.

Repertoár „Schizofrenie jako zkušenost“ byl identifikován v rozhovorech s odborníky. Schizofrenie je zde konstruována jako širší paleta prožitků či projevů, které společně představují specifickou zkušenost dotyčného. Nositel této zkušenosti, ji může integrovat a může pro něj být př́nosná. Může mu např́klad přinést nové pracovní možnosti („tu zkušenost zúročili způsobem, že sami vlastně vzdělávají, lektorují, superviduji ... dělají psychology, psychoterapeuty"). Svět člověka s touto zkušeností může být v mnohém zajímavější a bohatší. Z konstrukcí vyplývá, že lidé s ní např́íklad mohou vnímat více detailů a být citlivější $\mathrm{k}$ určitým podnětům. Konstruující zde zaujímají pozici tolerance $\mathrm{k}$ jinakosti a otevřenosti vůči odlišné zkušenosti druhých. Konstrukce často reflektují odlišnosti mezi jednotlivci a zdá se, že je pro odborníky v rámci tohoto repertoáru důležité vnímat individuální př́iběhy a to, čím právě člověk prochází. Konstruující se zde zříkají expertní pozice a jakoby odkládají své teoretické vzdělání, což koresponduje s tradicí otevřeného dialogu Jaakka Seikkuly (Seikkula \& Arnkil, 2013) a tento diskurz má velmi blízko $\mathrm{k}$ nevědoucímu př́stupu americké terapeutky Harlene Andersonové (2009). Daný repertoár má také blízko také k diskurzům „expertní neexpertnost“ a „laická pozice“, které identifikoval Šupa (2011) v rozhovorech s finskými zdravotními sestrami.

„Neexistující reprezentace schizofrenie“ byla identifikována v rozhovoru s laikem. Repertoár dokazuje, že pojem schizofrenie je některým lidem tak vzdálen, že o jeho významu nemají žádnou představu a nejsou ho schopni konstruovat vůbec. Neexistující reprezentace implikuje pozici nevědění, která může přinášet důsledky např́klad v podobě studu, touhy po vědění či komfortu jistoty, kterou by dotyčný při hádání významu pojmu ztrácel.

„Schizofrenik jako člověk představující nebezpečí je je repertoárem, v jehož rámci laici vyjadřovali obavy ze schizofreniků. Schizofrenik zde byl konstruován jako agresivní, vzteklý, nebezpečný svému okolí ale i sám sobě. $\mathrm{V}$ důsledku toho by měl být vyčleněn ze společnosti (,Že musej někoho třeba zabit nebo že ... prostě ty hlasy, že jim třeba našeptávaj, že to maj udělat."; ,jeví ehm vysoké znaky agresivity při tom, a podobně, tak tam asi nezbývá, než než nějakým způsobem je mít ehm vyčleněny, aby nemohli být nebezpečni svému okoli"). Konstruující se zde staví do pozice obežretnosti a opatrnosti. Zajímavým zjištěním je, že řada respondentů by ocenila informace od odborníka nebo rodiny člověka s diagnózou, což by snížilo jejich obavy. Chtěli by vědět, jak se k dotyčnému chovat, a dovedli by si pak lépe představit kontakt s ním. Zdá se tedy, že pozice, kterou tento repertoár implikuje, nemusí vycházet ze schizofrenikovy agresivity, ale může jít o strach z neznámého, který by bylo možné eliminovat. Tomu napovídá kromě vyjádřené touhy po informacích také skutečnost, že daný repertoár nebyl identifikován $\mathrm{v}$ rozhovoru s respondentkou, která má člověka s diagnózou ve své rodině, a jak sama uvedla, hodně o schizofrenii také četla. Tato zjištění částečně korespondují s výsledky britské studie (Furnham \& Blythe, 2012) ale i českého průzkumu z roku 2004 (DEMA, 2004), kde bylo zjištěno, že lidé, kteří mají osobní zkušenost s lidmi s diagnózou, $\mathrm{k}$ nim mají bližší postoj ${ }^{7}$. O širším diskurzu, kam tento repertoár spadá, pojednával např́klad Foucault (1993) ve svém díle, v němž dokládá, že myšlenka vyčlenění duševně nemocného ze společnosti není ničím novým. Jak ukazují výsledky analýzy, v určité formě jsou konstrukce tohoto typu stále aktuální. Daný diskurz přispívá ke stigmatizaci schizofreniků, kterým je přisouzen atribut, kvůli kterému jsou apriorně vnímání jako nebezpeční (Goffman, 2003). Obdobný diskurz byl identifikován i v dalších studiích (Bilić \& Georgaca, 2007;

\footnotetext{
${ }^{7}$ Zde je třeba podotknout, že diskurzivní analýza odmítá pojem postoj a nahrazuje ho pozicí, kterou daný interpretační repertoár umožňuje zaujmout.
} 
Nawková et al., 2010; Wilson et al., 1999), ve kterých byl zkoumán mediální obraz duševně nemocných. Ti zde byli často vyobrazováni jako agresivní či nebezpeční.

Repertoár „Schizofrenik jako člověk se sniženou kvalitou života“ byl identifikován v rozhovorech s laiky i odborníky a zahrnuje konstrukce, v nichž je život člověka s diagnózou negativně ovlivněn projevy schizofrenie. Člověk s diagnózou je zde konstruován jako ovlivnitelný a zneužitelný, mnohdy bez sociálních schopností a izolovaný např́íklad v souvislosti s pobíráním invalidního důchodu. Podle některých konstrukcí za sebe nemůže nést zodpovědnost, vést normální život a mít děti (,No, to si myslim, že ne. Že nemůže jako takhle normálně žit. "). Tato negativa mohou člověka s diagnózou dohnat až k pokusu o sebevraždu či k sebevraždě („Takže mám tady tu zkušenost ... a došlo to tak daleko teda, že si ubližil, že si podřezal žily a $\mathrm{krk}^{\prime}$ ). Tento repertoár umožňuje zaujmout pozici soucitu, která může ústit ve snahu pomoci dotyčnému snížit negativní projevy schizofrenie (,já právě o tom jsem i často si něco načitala, protože bych ho chtěla jakoby resocializovat"). Dále repertoár umožňuje zaujmout pozice obdivu nad tím, že lidé s diagnózou dokážou fungovat i navzdory radě omezení. Konstrukce vykreslující duševně nemocné jako selhávající, zranitelné, asociální a sociálně vyčleněné byly identifikovány také ve studii (Wilson et al., 1999) analyzující filmy, v nichž se objevuje duševně nemocný.

Repertoár ,Schizofrenik jako člověk, který pocit’uje strach“ se objevil v rozhovorech se všemi skupinami respondentů. Do tohoto repertoáru patř́ konstrukce, v nichž lidé s diagnózou zažívají silné pocity strachu v důsledku symptomů schizofrenie (,to mě řikají ty hlasy, že mě zabijí ... ustřelí nohu ... a že do spánku dostanu ránu nebo uřežou části těla “), ale také proto, že nevědí, co se s nimi v průběhu psychotické epizody dělo. Strach může být spojený také $\mathrm{s}$ hospitalizací. Lidé s diagnózou např́klad konstruovali obavy $\mathrm{z}$ toho, že budou jejich symptomy odhaleny a budou zavřeni do nemocnice („Ta schizofrenie tak funguje, že mášs strach $z$ doktorü, že na tobě něco poznaji a že tě teda zavřou do nemocnice, z toho jsem mél obrovskej strach, jo? “). Tato konstrukce vychází z přesvědčení, že člověk může být za svá provinění spočívající v odlišnosti perzekuován strážci normality v podobě lékařù. Tento diskurz existoval již ve středověku, kdy byli nositelé duševní nemoci pro svou odlišnost umíst'ováni do detenčních a nápravných zařízení (Černoušek, 1990; Foucault, 1993). Důsledkem pak může být dle konstrukcí nositelů diagnózy uzavření se ve vlastním světě a izolace nebo i sebepoškozování a pokus o sebevraždu. Člověk s diagnózou se v konstrukcích odborníků objevoval v bezmocné pozici. Mezi lidmi s diagnózou byla identifikována pozice disociace strachu od vlastní osoby - jako by strach patřil schizofrenii.

Repertoár ,Schizofrenik jako člověk, se kterým je jednáno jako s méněcenným či proti jeho vi̊li“ byl identifikován $\mathrm{v}$ rozhovorech $\mathrm{s}$ lidmi s diagnózou a $\mathrm{s}$ odborníky. V tomto repertoáru nejsou přání a potřeby člověka s diagnózou schizofrenie brány v potaz, je $\mathrm{s}$ ním jednáno jako s méněcenným. Může pak zažívat různé formy diskriminace, např́íklad nedobrovolnou hospitalizaci, nebo je nucen podstoupit léčebnou proceduru proti své vůli (,No to já jsem proti tomu ... s tím jsem vůbec nesouhlasil, že jsem to nechtěl podstoupit ... "). Zážitek méněcennosti je situován do pracovního, ale především do nemocničního prostředí, kde je s ním jednáno personálem z nadřazené pozice, což bylo konstruujícími s diagnózou vnímáno negativně. Obvykle by uvítali rovnocenný vztah a lidský př́stup lékaře, což je podle nich i žádoucí pro zdárný průběh léčby. Tato přesvědčení korespondují se závěry Šupy (2005), který zkoumal sociální reprezentace péče duševně nemocnými. Tento repertoár implikuje zaujetí znevýhodněné pozice, vyznačující se bezmocí, obviňováním, stěžováním si na chování těch, kteří využívají své moci. Repertoár spadá do širšího diskurzu o stigmatu. Osobě se stigmatem je přiřknut diskreditující atribut, s nímž již není dotyčný považován za plnohodnotného člověka, což druhé lidi z jejich pohledu opravňuje jednat s ním jako s méněcenným, a tím snižují jeho životní šance (Goffman, 2003). Tento diskurz byl běžnější v dobách, kdy byla duševní nemoc 
vnímána jako nedospělost či dětství, což bylo přesvědčení, ze kterého vzešla struktura nadřazenosti lékaře nad ne-mocným, který se $\mathrm{v}$ pozici dítěte musí podřizovat nařízeným léčebným postupům (Černoušek, 1990). Identifikace daného repertoáru dokladuje, že prvky tohoto diskurzu existují dodnes a byly identifikovány i v jiných studiích (Šupa, 2011; Wilson et al., 1999).

Poslední repertoár „Schizofrenik jako člověk, kterému se dostává pomoci okoli'“ byl identifikován $\mathrm{v}$ rozhovorech s odborníky, s lidmi s diagnózou a $\mathrm{v}$ rozhovoru s laikem. Za pozornost stojí, že laická konstrukce byla identifikována $\mathrm{v}$ rozhovoru s respondentkou, která byla jako jediná z laiků v blízkém kontaktu s člověkem s diagnózou, a lze si klást otázku, zda blízkost lidem s diagnózou podmiňuje výskyt daného repertoáru, čemuž nasvědčují i výsledky britské studie (Furnham \& Blythe, 2012). V identifikovaném repertoáru respondenti zmiňovali důležitost sociální opory a pomoci odborníků i blízkých pro jejich úzdravu. Oceňovali lidský prístup lékaře a vyjadřovali potřebu důvěřovat mu, což koresponduje s výsledky studie Šupy (2005). Respondenti s diagnózou zaujímali pozici vděčnosti jednak za léčbu ale i za blízkost druhých, kteří s nimi diagnózu prríliš nerozebírají a baví se s nimi o obvyklých věcech $(, \ldots$ voni to víceméně jako tak neřeši ... do extrému ... aji to mi celkem jako pomáhá ... že se to jako nerozebírá ... že spíš jako mluvíme o normálních věcech ... "). To koresponduje s Goffmanovým (2003) tvrzením, že př́lišná či nadbytečná pomoc a podpora může být dotyčným vnímána jako škodlivá a stigmatizující. Pomoc je lidmi s diagnózou konstruována šířeji než léčba, spadají sem také přátelské vztahy, soucit, lidský přístup nebo pocit, že jsou pro druhé důležití. Odborníky je jako nápomocný konstruován pravidelný režim, důvěra v léčbu, podpora okolí, možnost aktivně zasahovat do procesu léčby a vlastní motivace ke změně. Odborníci zaujímali aktivní pozici, ze které poskytují lidem s diagnózou individualizovanou podporu.

\section{Diskuse}

Z výsledků je patrné, že jednotliví respondenti využívali ke konstruování schizofrenie více z identifikovaných interpretačních repertoárů. Tato zjištění korespondují s tím, co uvádí ve své studii Reynolds s Wetherellovou (2003), totiž, že lidé běžně čerpají z většího množství diskurzivních zdrojů vytváření významu, využívají více různých interpretačních repertoárů a dle určitých kritérií si volí, jaký repertoár v danou chvíli použijí. Repertoáry, které jednotlivec využivá, si mohou i protiřečit. Vzájemně protichůdné repertoáry byly v předkládané studii skutečně identifikovány (např.: Schizofrenik jako člověk, se kterým je jednáno jako s méněcenným či proti jeho vưli“ a „Schizofrenik jako člověk, kterému se dostává pomoci okoli“.). Za pozornost stojí, že tyto protichůdné repertoáry využivali i stejní respondenti. $Z$ výsledků analýzy je také patrné, že tentýž repertoár může mít pro různé respondenty odlišné důsledky a může implikovat zaujímání rozdílných pozic. Tato zjištění korespondují s tvrzením Burrové (2003), která uvádí, že tentýž repertoár může být různými lidmi používán k naplňování různých cílů.

Předkládaná studie kvůli odlišné metodologii neumožňuje př́mé srovnání s francouzskou studií Castilla a kol. (2008), v níž byly identifikovány obdobné sociální reprezentace týkající se stigmatu u laiků a osob s diagnózou, což autoři vysvětlují tak, že lidé s diagnózou ze společnosti tyto reprezentace internalizovali. V předkládané studii bylo mezi laiky identifikováno několik repertoárů, které prř́mo podmiňují stigmatizaci („Schizofrenie jako rozdvojení osobnosti“, „Schizofrenik jako člověk, predstavujicí nebezpečí ${ }^{\prime \prime}$. U osob s diagnostikovanou schizofrenií byl identifikován pouze repertoár, ve kterém respondenti jen reflektují, jak stigmatizaci pocit’ují („Schizofrenik jako člověk, který pocituje strach“, „Schizofrenik jako člověk, se kterým je jednáno jako s méněcenným či proti jeho vůli“"). 
Lze tedy říci, že výsledky předkládané studie závěrům studie francouzské (Castillo et al., 2008) príliš nenasvědčují a nelze $\mathrm{z}$ nich vyvozovat, že by respondenti s diagnózou internalizovali stigmatizující konstrukce.

Zajímavé je srovnání repertoárů, v nichž byla konstruována úzdrava u osob s diagnózou se studií (Rudge \& Morse, 2001), ve které byl také zkoumán proces konstrukce úzdravy. Bylo v ní zjištěno, že proces úzdravy nemusí být konstruován jako lineární, a zároveň, že schizofrenie ze života dotyčného nezmizí, ale dotyčný se učí se svou diagnózou koexistovat, což se mu může podařit např́klad prostřednictvím náhlé jednorázové události. Schizofrenie se však stává součástí centrální identity dotyčného. V předkládané studii byla úzdrava konstruována především v repertoáru ,Schizofrenie jako zátěž“" a „Schizofrenie jako kariéra“. Konstrukce úzdravy se z velké části shodují s výše citovanou studií. Proces úzdravy zde rovněž nebyl vždy konstruován jako lineární proces (,A chodila jsem do práce. Vždycky dva roky jsem vydržela v práci, potom jsem se zhroutila. Léčila jsem se na psychiatrii a potom po určité době jsem se zase vracela do toho zaměstnání.") a rovněž byly identifikovány konstrukce, které nasvědčují tomu, že schizofrenie se stává součástí identity lidí s diagnózou (,No nebylo to ... prostě jsem se s tím učila žit, jo"; Nad tou nemocí ... nějak se učím s tím srovnat, že to mám ... nějak se s tím smírit" “).

Předkládaná studie přináší řadu předpokladů, vycházejících z konstrukcí respondentů, které by stály za další ověření kvůli případné aplikaci do praxe. Prvním předpokladem, kterému předkládaná výzkumná studie napovídá, je, že repertoáry umožňující zaujetí aktivní pozice jsou prospěšné v úzdravě. Dalším pak, že repertoáry implikující zaujetí mocensky nerovnocenné pozice úzdravě neprospívají. Ve výzkumu se také ukázalo, že řada laiků především v repertoáru „Schizofrenik jako člověk predstavujici nebezpeči", který obecně komplikuje dostupnost podpory, uváděla, že kdyby měli více informací o schizofrenii, snížily by se jejich obavy a dovedli by si pak lépe představit vzájemný kontakt. Dost možná by pak jejich pohled nebyl vůči těmto osobám tolik stigmatizující. Výsledky předkládané studie také ukazují ve shodě s britskou a českou studií (DEMA, 2004; Furnham \& Blythe, 2012), že se k lidem s diagnózou lépe staví ta část populace, která se dostala do osobního kontaktu s lidmi s diagnózou. V citovaných výzkumech založených na dotaznících byla respondenty daná informace pouze sdělena. V předkládané studii to potvrdilo př́mo užívání daných repertoárů a zřejmé to bylo také z konstrukcí respondentky, která má člověka s diagnózou v rodině. Zdá se tedy, že dostatek informací o diagnóze a osobní kontakt laiků s člověkem s diagnózou by mohl snižovat užívání potenciálně stigmatizujících repertoárů. Nabízelo by se např́iklad zkoumání repertoárů u laiků před a po absolvování edukačního programu či osvětové přednášky, kterou by prováděli přímo nositelé diagnózy. Př́nosné by mohlo být také zkoumání toho, odkud lidé své repertoáry ohledně schizofrenie čerpají. Mohlo by se takto zkoumat např́klad, nakolik lidé s diagnózou čerpají repertoáry od svých lékařủ a sociálních pracovníků. $Z$ výsledků analýzy nelze kauzálně doložit, že by repertoáry odborníků byly lidmi s diagnózou převzaty, nicméně se podařilo zachytit několik společných repertoárů u obou těchto skupin, což by mohlo danému předpokladu napovídat. V tomto směru by mohlo být př́nosné zkoumání, v němž by se srovnávaly repertoáry lékařů, sociálních pracovníků či psychologů přímo s repertoáry jejich klientů a pacientů s diagnózou. Ověření daných hypotéz by však již vyžadovalo jiný výzkumný design než diskurzivní analýzu výpovědí o daném tématu.

Použitá metoda kritické diskurzivní psychologie neumožňuje zobecnění na populaci ani zaměření se detailněji na život respondentů mimo výzkumný kontext. K tomu by mohly posloužit jiné, např́iklad narativní nebo biografické př́stupy. Limitem studie může být počet provedených rozhovorů. Lze předpokládat, že v našem prostředí existují další repertoáry, které se nepodařilo zachytit, a že vyšší počet respondentů by mohl analýzu ještě obohatit. Stejně tak by mohlo být př́nosné zahrnout do výzkumu více blízkých osob lidí s diagnózou. Ve výzkumu 
se taková respondentka objevila jediná a její prrítomnost v něm nebyla nijak cílená. Další slabinou by mohla být volba výzkumného souboru. Respondenti s diagnózou měli určité obdobné charakteristiky. Všichni byli z Brna a okolí, kde je péče o lidi s diagnózou poměrně dobře dostupná a zároveň se všem $\mathrm{v}$ době konání rozhovoru určité podpory dostávalo. Je možné, že zahrnutím respondenti̊ bez odborné péče nebo respondentů, kteří i přes svou diagnózu dosáhli samostatnosti či úplné úzdravy, by mohlo přinést výzkumem nezachycené repertoáry.

\section{Závěr}

Ve výzkumné studii byly prostřednictvím polostrukturovaných rozhovorů s laiky, lidmi s diagnózou a odborníky mapovány interpretační repertoáry ohledně pojmu schizofrenie. Pomocí metody analýzy dat - kritické diskurzivní psychologie bylo identifikováno celkem třináct interpretačních repertoárů, $v$ jejichž rámci respondenti schizofrenii nebo člověka s touto diagnózou konstruují. U každého repertoáru byly detailně analyzovány pozice, které daný repertoár umožňuje zaujmout, a byly také mapovány možné důsledky, které daný repertoár přináší. Identifikované repertoáry byly zařazeny do širších globálních diskurzů. Význam této studie spočívá v tom, že je v našem prostředí hlubší zkoumání významu schizofrenie ojedinělé. $\mathrm{Z}$ výzkumu také vyplynulo několik předpokladů, které by mohly být předmětem budoucího zkoumání a přinést řadu praktických aplikací pro terapeutickou i léčebnou praxi a pro vzdělávání veřejnosti za účelem snižování stigmatu.

\section{Literatura}

Adamíková, K. (2003). Psychóza očami klientom centrovaného terapeuta. Konfrontace, 14, 208-211.

Anderson, H. (2009). Konverzace, jazyk a jejich možnosti: Postmoderní přistup k terapii. NC Publishing.

Angermeyer, M. C., \& Matschinger, H. (2005). Causal beliefs and attitudes to people with schizophrenia: Trend analysis based on data from two population surveys in Germany. The British Journal of Psychiatry, 186, 331-334. https://doi.org/10.1192/bjp.186.4.331

Berger, P. L. \& Luckmann, T. (1999). Sociální konstrukce reality: Pojednání o sociologii vědění. CDK.

Bilić, B., \& Georgaca, E. (2007). Representations of „Mental Illness“ in Serbian newspapers: A critical discourse analysis. Qualitative Research in Psychology, 4, 167-186. https://doi.org/10.1080/14780880701473573

Boschma, G. (2007). Accommodation and resistance to the dominant cultural discourse on psychiatric mental health: Oral history accounts of family members. Nursing Inquiry, 14(4), 266-278. https://doi.org/10.1111/j.1440-1800.2007.00379.x

Brousard, B., Goulding, S. M., Talley, C. L., \& Compton, M. T. (2010). Beliefs about causes of schizophrenia among urban African American community members. Psychiatric Quarterly, 81, 349-362. https://doi.org/10.1007/s11126-010-9143-1

Burr, V. (2003). Social constructionism. Routledge.

Castillo, M. C., Lannoy, V., Seznec, J. C., Januel, D., \& Petitjean, F. (2008). Social representations of schizophrenia: A comparison between the general population and a sample of schizophrenics patients. L'évolution psychiatrique, 73, 615-628. https://doi.org/10.1016/j.evopsy.2007.06.006

Compton, M. T., Esterberg, M. L., \& Broussard, B. (2008). Causes of schizophrenia reported by urban African American lay community members. Comprehensive Psychiatry, 49, 8793. https://doi.org/10.1016/j.comppsych.2007.07.003 
Černoušek, M. (1990). Historie pojmu duševní zdraví a duševní nemoc: Studie k dějinám psychiatrického myšlení III. Výzkumný ústav psychiatrický v Praze.

DEMA (2004). Názory na schizofrenii: Reprezentativní výzkum v $\check{C} R$. DEMA, a.s.

Flick, U. (2009). An introduction to qualitative research. London: Sage Publications.

Foucault, M. (1993). Dějiny šilenství: Hledání historických kořenů pojmu duševní choroby. Lidové noviny.

Furnham, A., \& Blythe, C. (2012). Schizophrenia literacy: The effect of direct experience with the illness. Psychiatry Research, 198, 18-23. https://doi.org/10.1016/j.psychres.2011.12.025

Goffman, E. (2003). Stigma: Poznámky o způsobech zvládání narušené identity. Sociologické nakladatelství.

Hendl, J. (2008). Kvalitativní výzkum: základní teorie, metody a aplikace. Portál.

Jonesová, E., \& Ansen, E. (2004). Systemická párová terapie a deprese. Konfrontace.

Kant, I. (2001). Kritika čistého rozumu. Oikoymenh.

Křesadlo, J. (2001). Průvodce inteligentního laika džungli současné psychologie a psychiatrie. Periplum.

Lafrance, M. N. (2007). A bitter pill: A discursive analysis of women's medicalized accounts of depression. Journal of Health Psychology, 12, 127-140. https://doi.org/10.1177/1359105307071746

Lafrance, M. N., \& Stoppard, M. J. (2006). Constructing a non-depressed self: Women's accounts of recovery from depression. Feminism \& Psychology, 16, 307-325. https://doi.org/10.1177/0959353506067849

Leiderman, E. A., Vazquez, G., Berizzo, C., Bonifacio, A., Bruscoli, N., Capria, J. I., Ehrenhaus, B., Guerrero, M., Guerrero, M., Lolich, M., \& Milev, E. (2011). Public knowledge, beliefs and attitudes towards patients with schizophrenia: Buenos Aires. Social Psychiatry and Psychiatric Epidemiology, 46, 281-290. https://doi.org/10.1007/s00127-010-0196-0

Libman-Sokolowska, M., \& Nasierowski, T. (2013). The importance of hope in coping with schizophrenia. Psychiatria Polska, 47(5), 933-946.

Marie, D. \& Miles, B. (2008). Social distance and perceived dangerousness across four diagnostic categories of mental disorder. Australian and New Zealand Journal of Psychiatry, 42, 126-133. https://doi.org/10.1080/00048670701787545

Miovský, M. (2006). Kvalitativní prístup a metody v psychologickém výzkumu. Grada.

Moscovici, S. (2000). Social representations: explorations in social psychology. Polity Press.

Nawková, L., Adámková, T., Holcnerová, P., Nawka, A., Bednárová, B., Žuchová, S., Rukavina, T. V., Miovský, M., \& Raboch, J. (2010). Vyobrazení osob s duševním onemocněním v českých, chorvatských a slovenských tišsěných médiích. Česká a slovenská psychiatrie, 106(6), 351-356.

Olafsdottir, S., \& Pescosolido, A. P. (2011). Constructing illness: How the public in eight Western nations respond to a clinical description of "schizophrenia". Social Science \& Medicine, 73(7), 929-938. https://doi.org/10.1016/j.socscimed.2011.06.029

Öster, I., Åström, S., Lindh, J., \& Magnusson, E. (2009). Women with breast cancer and gendered limits and boundaries: Art therapy as a „safe space“ for enacting alternative subject positions. The Arts in Psychotherapy, 36, 29-38. https://doi.org/10.1016/j.aip.2008.10.001

Paulík, K. (2010). Psychologie lidské odolnosti. Grada.

Paulson, S., \& Willig, C. (2008). Older women and everyday talk about the ageing body. Journal of Health Psychology, 13, 106-120. https://doi.org/10.1177/1359105307084316 
Pěč, O., Vachková, L., Wogurková, D., Mužík, J., \& Krivošíková, M. (2009). Psychiatrická rehabilitace. In O. Pěč \& V. Probstová (Eds.), Psychózy: psychoterapie, rehabilitace a komunitní péče, (pp. 94-139). Triton.

Plichtová, J. (1998). Sociálne reprezentácie: Teória, výskum, výzva. Československá psychologie, 42(6), 503-520.

Plichtová, J. (2002). Metódy sociálnej psychológie zblizka: Kvalitatívne a kvantitatívne skúmanie sociálnych reprezentácií. Média.

Potter, J., \& Wetherell, M. (1987). Discourse and Social Psychology: Beyond Attitudes and Behaviour. Sage Publications.

Potter, J., \& Wiggins, S. (2007). Discursive psychology. In C. Willig, \& W. Stainton-Rogers (Eds.), The Sage handbook of qualitative research in psychology, (pp. 73-90). Sage Publications.

Reynolds, J., \& Wetherell, M. (2003). The discursive climate of singleness: The consequences for women`s negotiations of a single identity. Feminism \& Psychology 13(4), 489-510. https://doi.org/10.1177/09593535030134014

Richards, M., Hori, H., Sartorius, N., \& Kunugi, H. (2014). Cross-cultural comparisons of attitudes toward schizophrenia amongst the general population and physicians: A series of web-based surveys in Japan and the United States. Psychiatry Research, 215, 300-307. https://doi.org/10.1016/j.psychres.2013.12.012

Rudge, T. \& Morse, K. (2001). Re-awakenings? A discourse analysis of the recovery from schizophrenia after medication change. Australian and New Zealand Journal of Mental Health Nursing, 10, 66-76. https://doi.org/10.1046/j.1440-0979.2001.00196.x

Sawamura, K., Tachimori, H., Koyama, T., Koyama, A., Naganuma, Y., Kim, Y., \& Takeshima, T. (2012). Lay Diagnoses and Views on Causes, Coping Strategies, and Treatment for Schizophrenia. Community Mental Health Journal, 48, 309-316. https://doi.org/10.1007/s10597-011-9454-1

Seikkula, J., \& Arnkil, T. E. (2013). Otevřené dialogy: Setkávání sití klienta v psychosociální práci. Narativ.

Schütz, A. \& Wagner, H. R., (1970). Alfred Schutz on phenomenology and social relations: selected writings. University of Chicago Press.

Swami, V., Furnham, A., Kannan, K., \& Sinniah, D. (2008). Beliefs about schizophrenia and its treatment in Kota Kinabalu, Malaysia. International Journal of Social Psychiatry, 54(2),164-179. https://doi.org/10.1177/0020764007084665

Šafářová, Š. (2011). Srovnání konceptů schizofrenie v odborné česky psané literatuře 20. a 21. století [Diplomová práce]. Filozofická fakulta, Masarykova univerzita, Brno.

Retrieved from: http://is.muni.cz/th/141838/ff_m/sarka_safarova_DP.pdf

Št’astný, F. (2008). Schizofrenie z pohledu staletí. Vesmír 87, 372.

http://www.vesmir.cz/clanek/schizofrenie-z-pohledu-staleti

Šupa, J. (2005). Sociální reprezentace duševně nemocného u studentů psychologie, studentů medicíny a studentek v oboru zdravotní sestra na psychiatrii a sociální reprezentace péče v psychiatrických zařízeních podle lidí zde hospitalizovaných. In M. Miovský, I. Čermák, \& V. Chrz (Eds.), Kvalitativní přistup a metody ve védách o člověku IV, (pp. 261-277). Univerzita Palackého v Olomouci.

Šupa, J. (2011). Od člověka k diagnóze a od diagnózy k člověku. Disertační práce. Fakulta sociálních studií, Masarykova univerzita, Brno. Retrieved from: https://is.muni.cz/auth/th/12167/fss_d_a2/Disertacni_prace_J_nobgytei._Supa.pdf

Teräsahjo, T., \& Salmivalli, Ch. (2003). "She is not actually bullied." The discourse of harassment in student groups. Aggressive Behavior, 29(2), 134-154.

https://doi.org/10.1002/ab.10045

Urbánek, E. (1989). Kritika fenomenologické sociologie. Univerzita Karlova. 
Vybíral, Z. (2006). Psychologie jinak: Současná kritická psychologie. Academia.

Wilkinson, S. (2000). Women with breast cancer talking causes: Comparing content, biographical and discursive analyses. Feminism \& Psychology, 10(4), 431-460. https://doi.org/10.1177/0959353500010004003

Willig, C. (2008). Discourse analysis. In J. A. Smith (Eds.), Qualitative psychology: A practical guide to research methods, (pp. 159-183). Sage/Open University.

Wilson, C., Nairn, R., Coverdale, J., \& Panapa, A. (1999). Mental illness depictions in primetime drama: identifying the discursive resources. Australian and New Zealand Journal of Psychiatry, 33, 232-239. https://doi.org/10.1046/j.1440-1614.1999.00543.x

Zábrodská, K. (2009). Variace na gender. Poststrukturalismus, diskurzivní analýza a genderová identita. Academia.

Zábrodská, K. (2010). Diskurzivní analýza v soudobé sociální psychologii: teorie, koncepty a aplikace. Československá psychologie, 54(3), 249-262.

Zábrodská, K., \& Petrjánošová, M. (2013). Metody diskurzivní analýzy. In T. Řiháček, I. Čermák, \& R. Hytych (Eds.), Kvalitativní analýza textů: čtyři př́stupy, (pp. 105-138). Masarykova univerzita.

\section{Údaje o autorovi}

PhDr. Ing. Jan Pokluda je psycholog, psychoterapeut a student doktorského studia klinické psychologie na FF MU. Je zaměstnán v Terapeutickém centru v Jihomoravském kraji Společnosti Podané ruce o.p.s., kde terapeuticky pracuje s klienty se závislostmi a jejich blízkými. V Brně také provozuje soukromou terapeutickou praxi. Mezi oblasti jeho zájmu patří využití hypnózy v terapii, systemické, strategické a na řešení zaměřené terapeutické směry a výzkum psychoterapie.

\section{Kontaktní údaje:}

Adresa: Horní Újezd 133, 57001 Litomyšl

E-mail: pokluda.jan@seznam.cz

Pokluda, J. (2020). Schizofrenie v českém prostředí: diskurzivní analýza výpovědí o schizofrenii. E-psychologie, 14(4), 1-15. https://doi.org/10.29364/epsy.381 